\title{
Documentation, using GIS techniques in conservation of a World Heritage Site, a case study of "The Old City of Jerusalem"
}

\author{
B.Husseini*, Z.Bali \\ ${ }^{a}$ Welfare Association, OCJRP-Old City of Jerusalem Revitalization Program, Palestine - husseinib@jwelfare.org, \\ bashar3h@hotmail.com
}

KEY WORDS: Documentation, Old City of Jerusalem, GIS, Database, Historic Buildings, Architectural Conservation

\begin{abstract}
:
Architectural Heritage is a strong witness to a people's history that symbolizes their identity. The Old city of Jerusalem, and as a UNESCO world heritage site ${ }^{1}$ is a living city especially with its great wealth of historic structures, including places of worships for the three monotheistic religions, significant monuments, and whole historical residential neighbourhoods, Figure 1.

In spite of the prevailing political conditions, difficulties that Palestinians encounter in Jerusalem, and the demands of the modern life and ever-growing population, several attempts had been stimulated to protect this Heritage. A specialized program (Old City of Jerusalem Revitalization Program - OCJRP) has been working since 1994. The program was established by the Welfare Association ${ }^{2}$ to help protect Jerusalem's cultural heritage applying international conventions and the highest professional standards for the direct benefit of residents, building users and visitors to the Old City as well as for future generations.
\end{abstract}

This paper aims to describe the various activities and main findings carried out by the Technical Office of OCJRP - in the last twenty years as well as stressing on problems encountered by the team. It will rely on the team experience accumulated during the implementation of the projects, the research, surveys and studies undertaken by the team who helped in the creation of the database and its ongoing process.

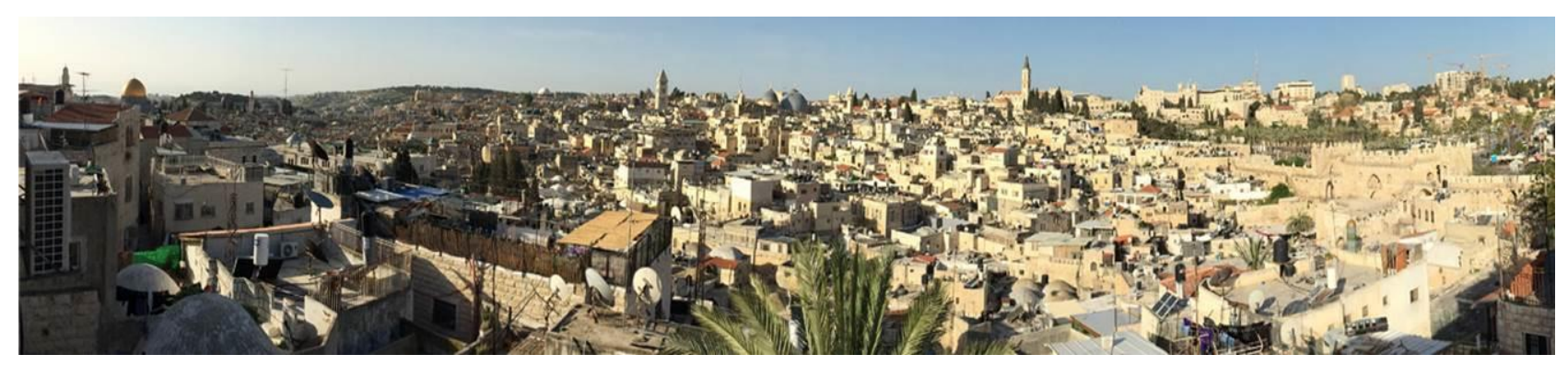

Figure 1. General view of the Old City of Jerusalem

\section{INTRODUCTION}

Documentation is one of the major principals of Conservation of Cultural Heritage to be able to establish necessary documents that allow later to develop both suitable approaches and criteria for appropriate buildings interventions. It serves as a tool to make information accessible to those who cannot investigate the property itself. It is also an integral part of the conservation process that should be based on thorough research, physical and analytical surveys.

The struggle to safeguard Jerusalem's cultural and architectural identity has led the Palestinian institutions, notably the Welfare Association to initiate and implement a comprehensive program for economic and social regeneration of the Old City and the conservation of its exceptional Cultural Heritage.

\footnotetext{
* Corresponding author
}

${ }^{1}$ The Old City of Jerusalem, including its magnificent historical walls, the city was inscribed as a UNESCO World Heritage Site in 1981 and on the UNESCO list of World Heritage in Danger in 1982.

${ }^{2}$ The Welfare Association (WA) is an independent non-profit organization established in 1983 by a group of Palestinian business and intellectual figures to provide development and humanitarian assistance to Palestinians in the West Bank including Jerusalem, the Gaza Strip, 1948 Areas, \&the Palestinian communities in Lebanon. Old City of Jerusalem Revitalization Program (known as OCJRP) established by the Welfare Association in 1994 in order to achieve sustainable development and renewal of Jerusalem's much neglected Old City. 
OCJRP through its several components is undertaking this ongoing process of documentation; it is comprised of four main components, which are implemented in parallel; and they are:

Architectural conservation component based by implementing various restoration projects inside and around the Old city of Jerusalem as well as other cities in Palestine especially Nablus Old City, this component has started working in the late nineties of last century and is has been formulated into a functioning unit.

Community awareness of cultural Heritage component: which aims to increase the community awareness among the residents of the Old City and other stakeholders and encourage them to participate in the protection of cultural and architectural heritage,

Specialized training and capacity building in Architectural Conservation component: Through implementing, several professional training workshops for professionals, contractors and workers. These activities include an internship program for new graduates, short and long term specialized courses in Architectural conservation and management of built heritage, as well as for an apprentice program for craftsmen and skilled workers, In 2007 WA institutionalized its training effort by developing an institute for architectural heritage.

- Information and documentation Centre component: To create and information and documentation centre based on research, studies and relevant surveys. This has being achieved originally by establishing a comprehensive database for the Old City based on extensive research and field surveys, and had been developed and is continuing as an ongoing process since the establishment of OCJRP till now. In addition to that, the Technical Office team prepared and published a number of publications and leaflets over the years, Figure 2.

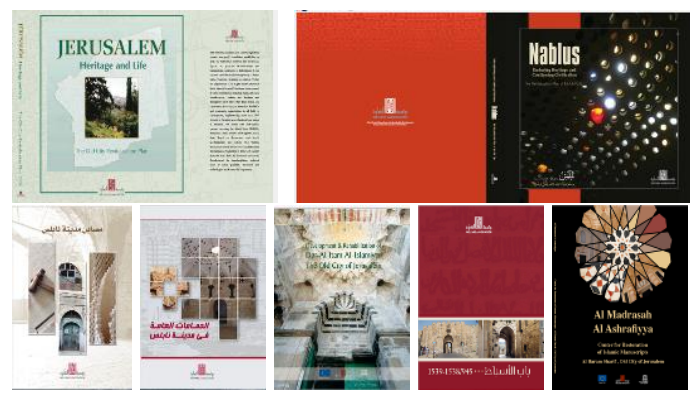

Figure 2. Some of OCJRP publications (Jerusalem Revitalization Plan, Nablus Revitalization Plan and other brochures)

\section{OLD CITY GIS DATABASE:}

The original OCJRP "Project Document" included the establishment of the information and documentation centre that would create a comprehensive database for the Old City of Jerusalem as well as carry out the publication of books, booklets and documents. By the year 1999, OCJRP owned the first geographical information system for most of the buildings and monuments inside the Old City of Jerusalem, in which several informatical layers were created. The database outputs were initially created to be used to determine the priorities of restoration interventions inside the Old City, but the results were later used for further wider goals for the benefit of Architectural Conservation as well as for the benefit of the Old City Inhabitants and users. This process in such a complex city faces many challenges, starting from the available used technologies to the most updated techniques, Figure 3.

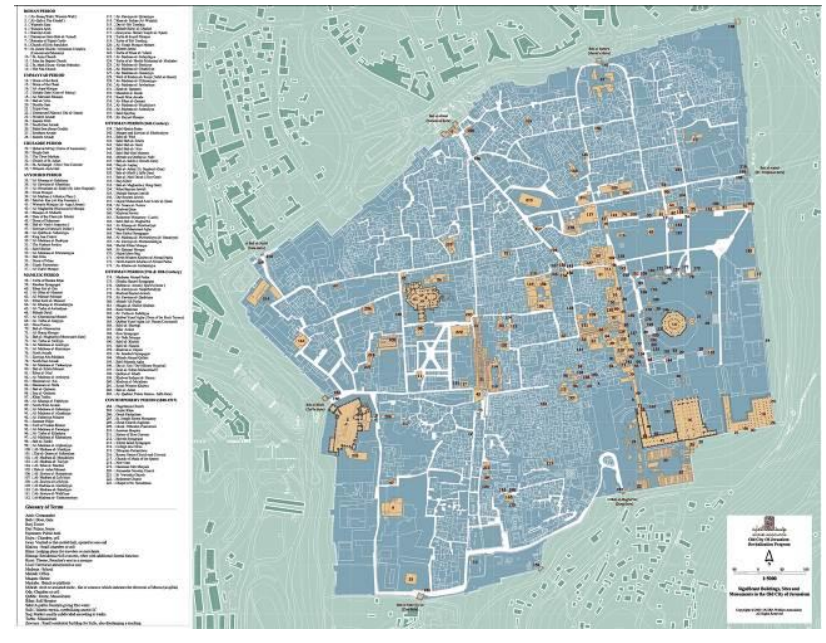

Figure 3. GIS Map showing the major Historical monuments inside the Old City of Jerusalem

The paper will mention some of the documentation methods used to update the database continuously.

\section{THE OLD CITY REVITALIZATION PLAN AND ITS IMPLEMNTATION:}

The multi-sector revitalization plan originally aimed to direct the development process in the Old City to regenerate the city's social and economic base which was prepared over a period of three years. In addition, it aimed to be as a basic guideline for planners and other professional, to create a nucleus for a comprehensive, diverse and integrated development process not only to protect the city's Cultural Heritage but also to improve the living conditions of its residents. All implemented according to international laws and conventions to protect the place and the person. A number of experts and specialists contributed to the production of this plan.

One of The findings of the plan showed that certain neighbourhoods suffered from socio economic problems as well as physical deterioration, which stimulated the team to conduct a thorough social, physical, legal and physical survey of the buildings. Consequently, a pilot study for a specific priority area was selected out of 48 areas divided by the Technical 
Office in which a detailed rehabilitation plan were prepared and partially implemented, Figure 4.

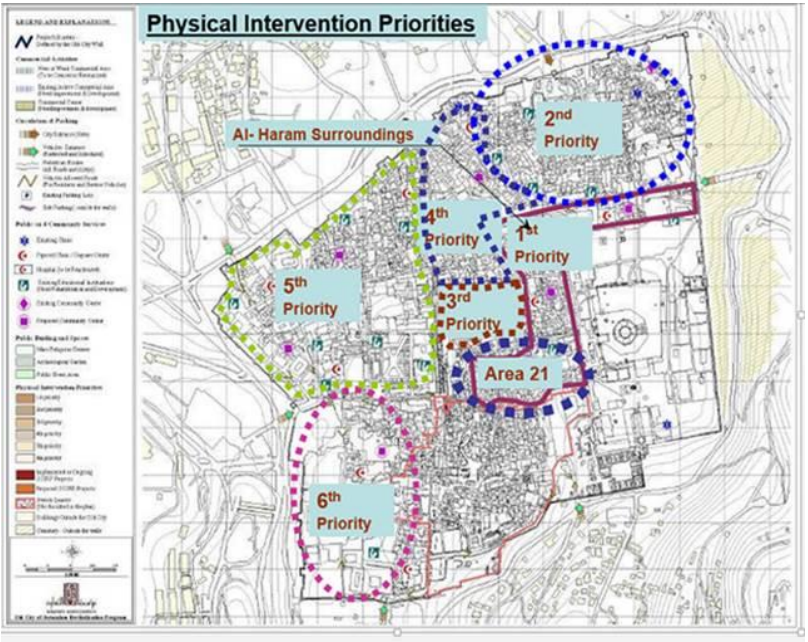

Figure 4. GIS Map showing the priority areas that was taken into consideration inside the Old City of Jerusalem

The plan is in an ongoing process to implement the plan on phases as it represents the first Palestinian plan for Arab Jerusalem which offers the planner, the professional, the researcher and the expert guidance to the right direction.

The concept of the plan was based on realities of Jerusalem as a living city suffering from social, economic and institutional decline, environmental degradation and physical dilapidation of buildings and harsh political and security conditions within this valuable cultural and religious context of the city.

However, under the ongoing prevailing political conditions and exceptionally difficult circumstances reflecting the hard conditions the city and its people had to endure under the occupation, as well as the prohibition on entry of Palestinians from other areas of Palestine, the whole comprehensive plan could not be implemented. The sustainability of the works forced the team to include the possibility of separating infrastructure works from physical restoration of residential complexes or $\left(\right.$ ahwash $\left.^{3}\right)$ instead of entire neighbourhoods.

\section{THE ONGOING PROCESS OF DOCUMENTATION USING GIS AND OTHER METHODS:}

The Revitalization plan and its findings, along with the conservation process as well as other components of OCJRP that were created in later stages erected the team for later steps and initiatives.

\subsection{Creation of the Original Database:}

As indicated before a GIS database was created during the creation of the first and only Palestinian Revitalization Plan. The database is based on a comprehensive field survey of over 3726 buildings and sits within the city walls covering

${ }^{3} \mathrm{HOSH}$ is group of adjacent residential buildings grouped together around a courtyard, which is common in Historical Arab architecture. architectural styles, historic periods, building use, and physical and structural conditions of the buildings and other characteristics of each building and neighbourhoods of the Old City of Jerusalem. The database was first created in 1999 and used since then as a base for all later documentation in OCJRP work, Figure 5.

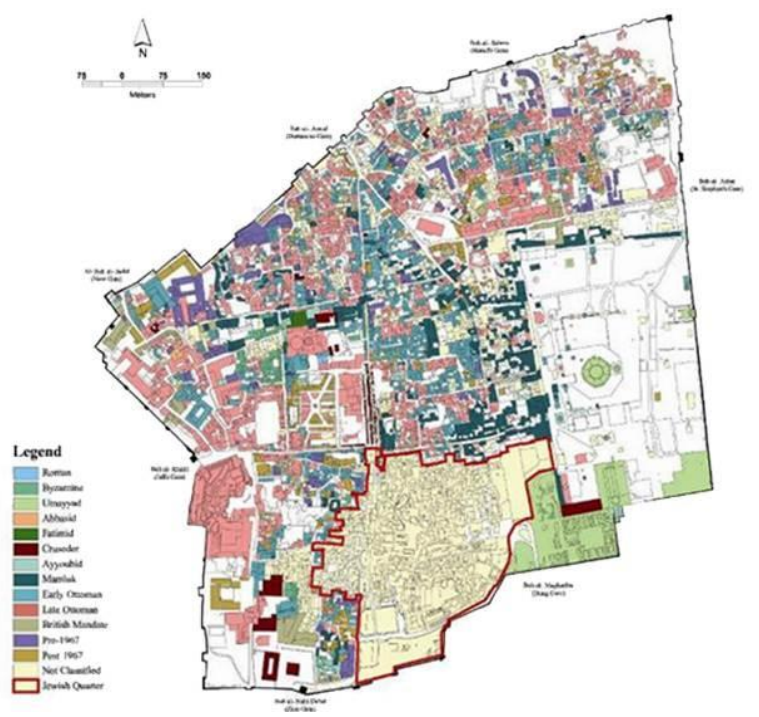

Figure 4. GIS Map showing the historical periods of buildings inside the Old City of Jerusalem

\subsection{Continuous update for Restoration Projects:}

Restoration projects in OCJRP starts with investigating the existing condition of the building or residential complex in which all available information is collected. This information collection starts from the existing GIS database of the property, and afterwards all needed information and documentation is collected from the site itself or from any other needed and available reference. In addition to this, the need assessment study as well as all the other analytical studies, surveys, photos, and any documentation needed to prepare the intervention plan for the restoration project are collected. After preparing the $\mathrm{BOQ}$, tendering and the implementation of the project is completed, all the information is collected and inserted in OCJRP database. This is the ongoing process is still implemented for all OCJRP projects, Figure 5.

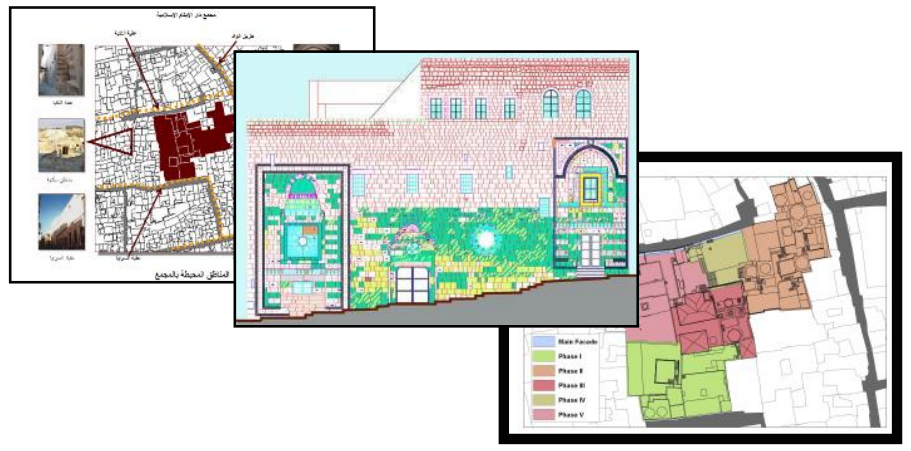

Figure 5. Collection of information inserted in the GIS Database 


\subsection{Ownership Documentation:}

Along the years of OCJRP work, one of the findings of the master plan was the absence of ownership documentation. This was a difficulty not only inside the Old City of Jerusalem but also in East Jerusalem as a whole; as extensive areas are been registered in the Land registry; either because nobody registered them or because their entry was destroyed or lost.

During the rule of the Ottomans Jerusalem (from 1516 until 1917), the properties registration was done by the Legal court. After that and during the British mandate rule (from 1917 until 1948) the government started to register the properties as well as recording selling them referring to 59 parcels. During Jordanian rule to Jerusalem, the government continued the operation until 1967 but with a different forms and system, which complicated the research. (Tafakji, 2013). In addition, since 1967 until now, the Israeli authorities didn't register the properties except in the newly demolished and reconstructed so called "Jewish Quarter".

The first phase of the documentation from various available documents here in Palestine, Jordan and other areas completed the identification of about $20 \%$ of the properties ownerships', this was low percentage because of the difference of registration system between the British mandate and the Jordanian government during their rule to Jerusalem. After this obstacle, the research is been followed by an extensive field survey and all the results is collected and documented in the GIS database, Figure6. The Technical Office of OCJRP will publish the results of the studies and the ongoing research soon.

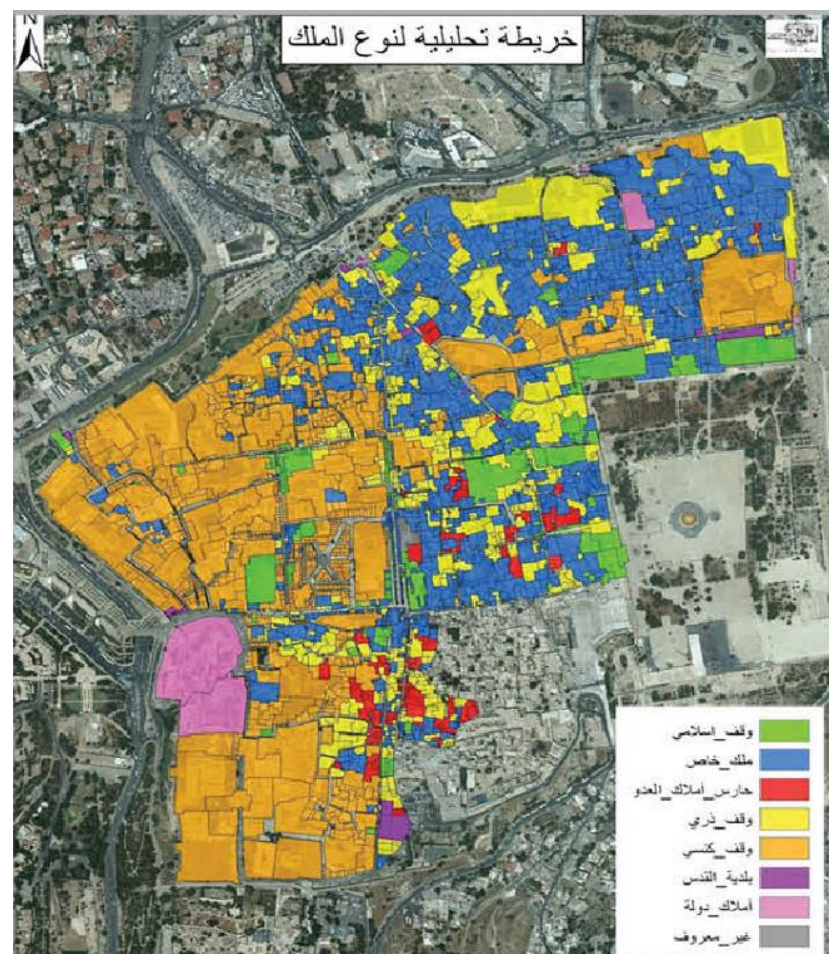

Figure 6. GIS Database of the properties distribution inside the Old city during the rule of Jordan to Jerusalem
4.4 Rebuilding demolished Al-Magharbeh, Sharaf and Jewish neighbourhoods Documentation:

All the studies of the OCJRP team excluded the now called "Jewish Quarter" from their work, studies and research, but it was realized that there is a big importance of documenting the demolished neighborhoods especially because it was recently registered in the Israeli land registration office (Tabu) with owners other than the original ones.

Immediately after Israel occupied East Jerusalem in 1967 the Old City of Jerusalem lost about $12 \%$ of its urban fabric. The entire Al-Maghariba and Sharaf neighbourhoods were demolished and evicted from Palestinian residents to create a huge plaza for the Jewish worshippers in front of the western wall of Haram al-Sharif, Figure 7, Figure 8. This is been followed by a series of expropriating Palestinian and Islamic waqf properties and demolition of historic buildings (Mustafa, 1997). Later on the now called, the "Jewish Quarter" was built on the ruins of historic houses and monuments and the lives of their inhabitants. About 700 historical buildings were demolished, including two mosques, four schools, 437 shops, and about 1048 residential units occupied by about 6000 Palestinian residents (Ricca, 2007).

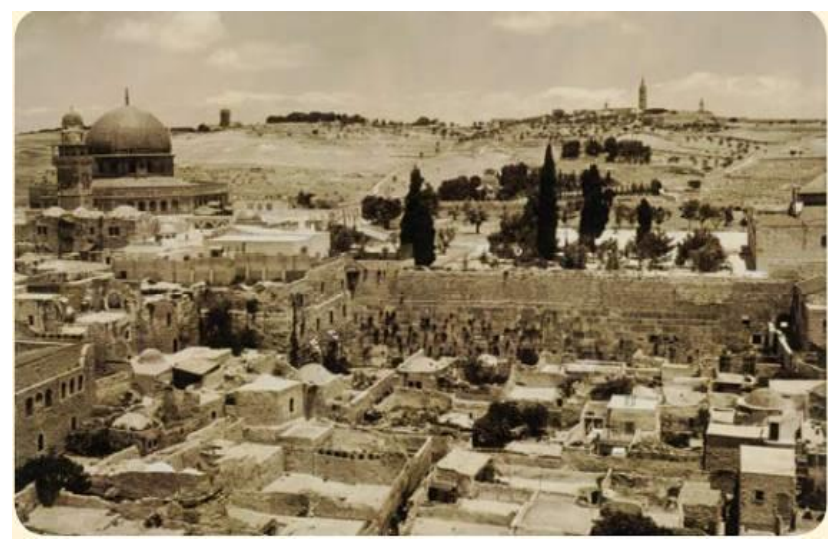

Figure 7. Al-Maghariba and Sharaf neighbourhoods before demolition dated from 1930 (Reference Aqsa, 2007)

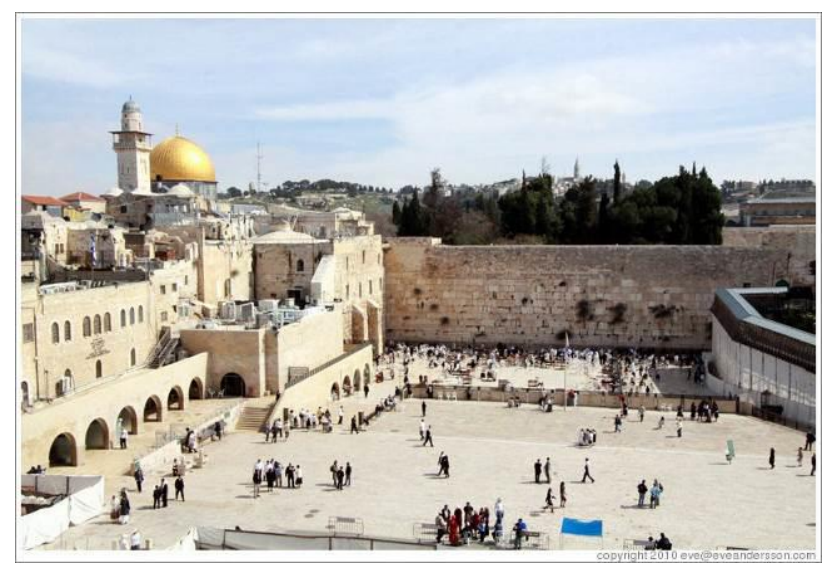

Figure 7. The walling wall after demolition of Al-Maghariba and Sharaf neighbourhoods

(Refernce http://www.eveandersson.com/photo-

display/large/israel/jerusalem-jewish-quarter-western-wall.html) 
The ownership documentation of these neighborhoods is still ongoing and supposed to finish soon. All the results are been collected and documented in the GIS database, Figure9, Figure10. The Technical Office of OCJRP will also publish the results of the studies and research soon.

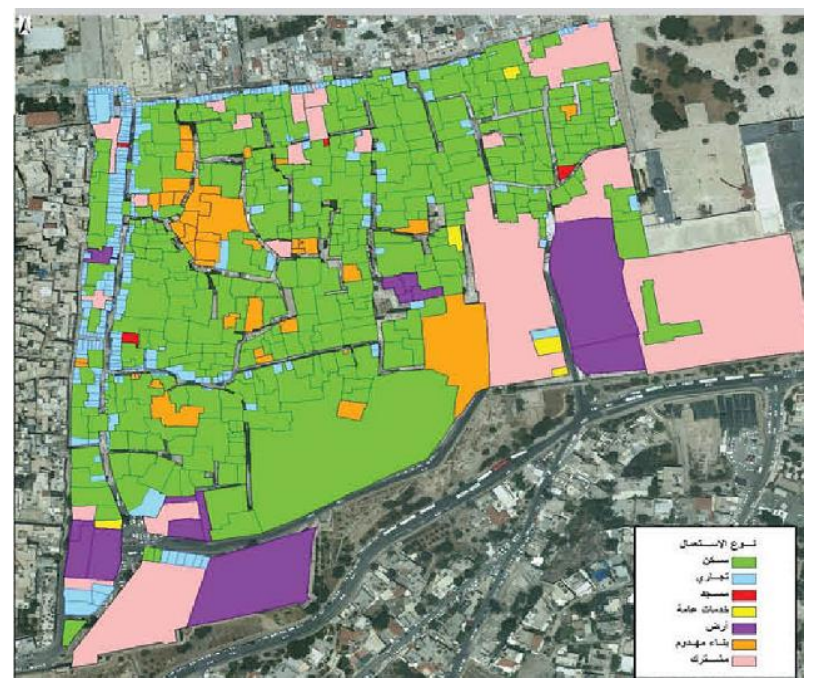

Figure 9. GIS Database of the uses of the properties inside the Jewish neighbourhood before demolition

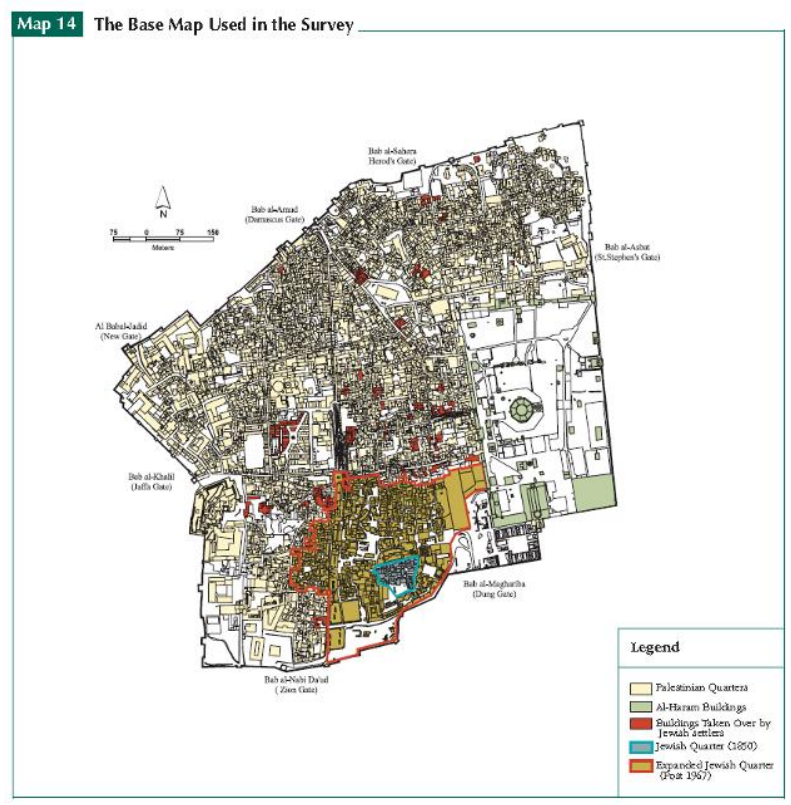

Figure 10. GIS Database showing of the location the Jewish neighbourhood post 1967

\subsection{Housing Condition Survey:}

Since the original data of the GIS database was collected since about 18years ago, OCJRP was obliged to update the information of the database, especially in the residential areas of the Old City. A detailed assessment will be conducted during the project to cover structural, physical and environmental conditions of the residential units in the selected neighbourhoods inside the Old city, Figure 11.
The aim of the study is to identify the updated main problems and condition of housing inside the old city, thus identify priorities and needs to provide a technical basis of interventions in the future.

A qualitative and quantitative data will be obtained from the field survey in which at least 300 residential units will be covered. The $1^{\text {st }}$ phase is now finished and the whole survey is expected to be completed by the end of this year.

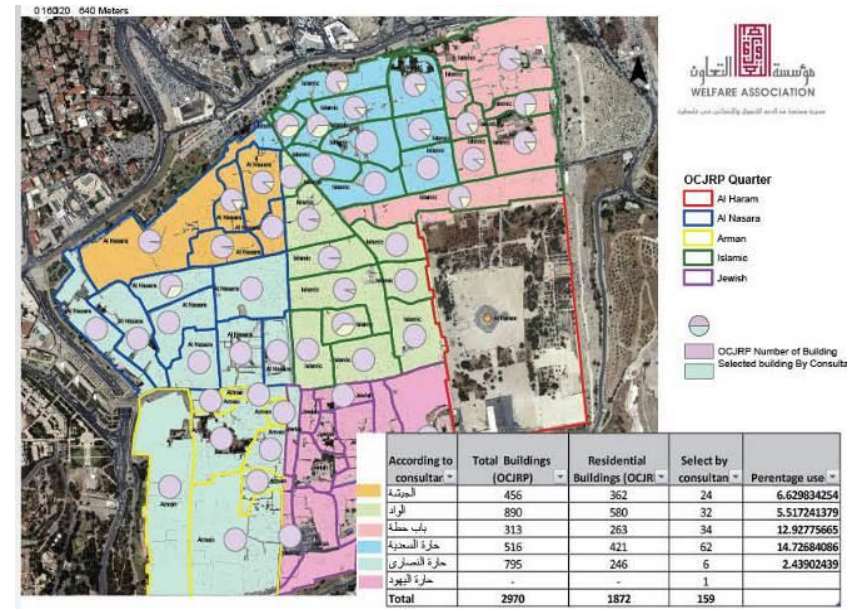

Figure 11. GIS map for the selection of the housing unit all over the Old City

\subsection{Android Mobile Application (Live Jerusalem):}

One of the remarkable initiatives, the Technical Office of OCJRP initiated in cooperation with a local institution (Burj AlLaqlaq Centre ${ }^{4}$ ) is the "Live Jerusalem" android application, Figure 12.

The initiative is a part of the community awareness program to the importance of Cultural Heritage. This application was prepared about 2 years ago and it is available and can be downloaded (free of charge) from any android smartphone or tablet. The application targets the users and visitors of the Old City of Jerusalem (including tourists).

It offers a tour to the major historic landmarks of the Old City to strengthen the relationship between the people and the city's landmark, through providing information about the landmark to the user during his tour including maps, photos and historical information. This initiative is one of the first initiatives from Palestinian institutions concerning this field.

\footnotetext{
${ }^{4}$ Burj Al-Laqlaq is a social center located at the northeastern edge of the Old of Jerusalem. It provides several activities to the community of the Old City, it offers a football and basketball playgrounds, in addition to social activities and recreational open spaces.
} 


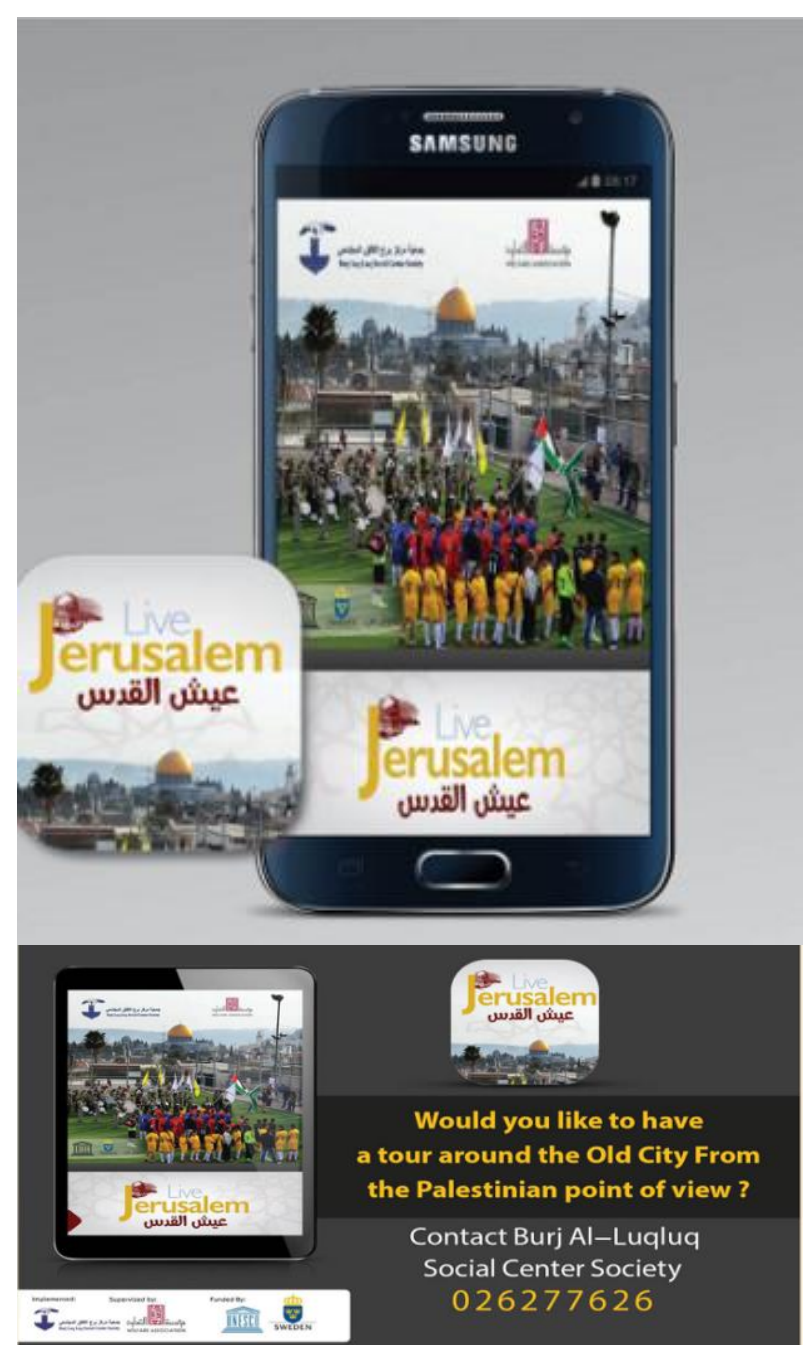

Figure 12. Photos showing the android application "Live Jerusalem"

\subsection{Architectural and Historical Studies:}

The ongoing process of the documentation, urged the database to be continuously updated, several Architectural and Historical studies were completed and published, one of them is the updated map of the major monuments inside the Old City which is still undergoing a further research, Figure 12, Figure 13.

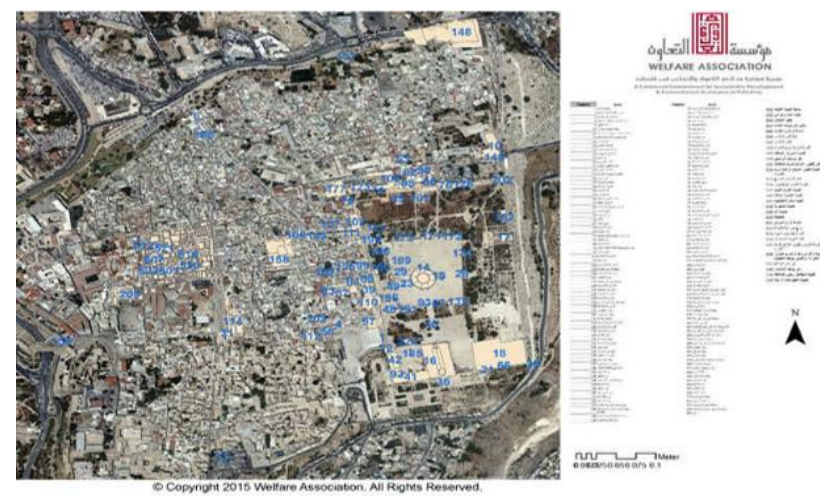

Figure 12. Map showing the major monuments inside the Old City

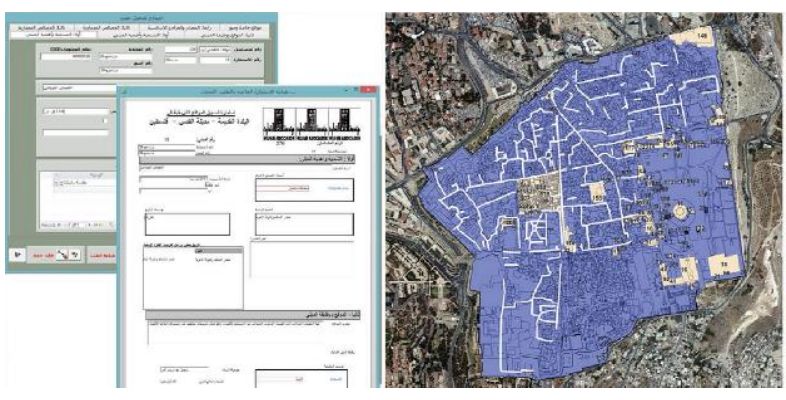

Figure 12. Photos showing documentation of studies

\section{CONCLUSIONS}

The protection of the Cultural Heritage as a whole and Architectural Heritage specifically requires the collaboration of different parties not just through institutions but also together with the local community. A dynamic and flexible approach based on diverse and mutli-disciplinary skills is required.

To succeed in affecting a positive change in the life of inhabitants of the Old City while protecting its heritage; the Welfare Association through the Technical office of OCJRP is trying their best to protect the city's cultural heritage. This is not just through implementing restoration projects but also through the documentation of its heritage in the past, present and even the future through applying GIS as well as other applications.

As stated in the paper, applying GIS in the work of the OCJRP had a great impact in documenting the history of such a unique city and making sure information is been collected and archived for current and future generations.. In addition, as GIS is a wide application with various functions, the OCJRP team has been able to benefit from this system to improve the work they daily conduct as well as introducing new processes to achieve a better outcome benefiting the Old City community.

\section{REFERENCES}

Dumper, M., 2002. The politics of sacred space: the old city of Jerusalem in the Middle East, Lynne Rienner Publisher, and London, United Kingdom.

Dumper, M., 1991/1992. Israeli Settlement in the Old City of Jerusalem, Journal of Palestinian Studies.

Ricca,S., 2007. Reinventing Jerusalem: Israel's Reconstruction of the Jewish Quarter after 1967, First Edition. I. B. Tauris, London, United Kingdom.

Welfare Association, 2004. Jerusalem, Heritage and Life, Second Edition. Jerusalem.

\section{ARABIC REFERNCES:}

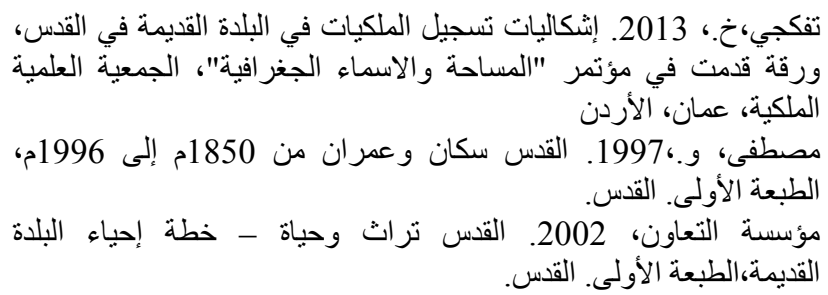

